\title{
STORAGE POTENTIAL OF SEEDS OF MAIZE COLLECTION SAMPLES (ZEA MAYS L.)
}

\author{
Corlateanu Liudmila*, Mihaila Victoria, Ganea Anatolii
}

Institute of Genetics, Physiology and Plant Protection of the Academy of Sciences of Moldova,

Moldova, Chisinau

\section{ПОТЕНЦИАЛ ХРАНЕНИЯ СЕМЯН КОЛЛЕКЦИОННЫХ ОБРАЗЦОВ КУКУРУЗЫ (ZEA MAYS L.)}

\author{
Корлэтяну Людмила, Михаилэ Виктория, Ганя Анатолий \\ Received 26. 6. 2017 \\ Revised 28. 6. 2017 \\ Published 2511.2017
}

The main condition for secure ex situ conservation of germplasm in plant gene banks is the necessity to preserve the viability of seeds, their physiological quality and to minimize aging rate. Loss of physiological quality of seeds results in yield decrease and low quality of seeds, loss of their uniformity and worsening of growth and development of plants as well as low resistance to environmental stresses. Production of seeds with high germinability is not sufficient per se. To ensure high storage potential of seeds it is necessary not only to obtain seed material with high viability but also to ensure its correct storage with the purpose of maintaining initial germinability. Therefore it is very important to determine storage potential of genotypes before placing them for long-term storage and to rank by this trait of valuable collection material. Use of test for accelerated aging of seeds (AA) allowed determination of genotypic features of maize collection accessions and their grouping by a potential capability of preservation of seed viability after the exposure to stress factors (increased temperature and humidity). With the help of morphophysiological (germination power and germinability of seeds, length of seedling rootlets, fresh and dry biomass of seedlings, electric conductivity of seeds) and biochemical (peroxidase activity) parameters of seeds and seedlings there has been determined storage potential of various genotypes of maize that is an important complex characteristics of collection accessions when they are placed for long-term storage in plant gene bank. Determination of storage potential allows revealing samples inappropriate for long-term storage and saving resources for conservation, as well as giving recommendations about reproduction of seed material and necessity to restore the viability of collection accessions using different physicochemical factors.

Keywords: maize; storage potential; accelerated aging; germination power, germinability; peroxidase; length of rootlets; biomass of rootlets

\section{Введение}

Основным условием гарантированной консервации ех situ зародышевой плазмы в генетических банках растений является необходимость сохранения жизнеспособности семян, их физиологического качества и сведение до минимума скорости старения. В последнее время

*Corresponding author: Liudmila Corlateanu, Institute of Genetics, Physiology and Plant Protection of the Academy of Sciences of Moldova, Moldova, Chisinau, $\triangle$ Icorlateanu@yahoo.com 
в научной литературе активно используется термин «потенциал хранения семян» (Demir and Mavi, 2008; Havstad et al., 2011; Mielezrski and Marcos-Filho, 2013; Nirmala and Umarani, 2014; Aghilian et al., 2014). Потенциал хранения ортодоксальных семян определяется такими факторами как качество семян, обусловленное условиями во время формирования семян, и временем между физиологической зрелостью и урожаем (Villela and Menezes, 2009).

Потеря физиологического качества семян приводит к снижению урожая и низким стандартам семян, к потере их однородности, а также к ухудшению роста и развития растений и низкой устойчивости к экологическим стрессам. Производство семян с высокой всхожестью недостаточно само по себе. Чтобы обеспечить высокий потенциал хранения семян необходимо не только получить семенной материал с высокой жизнеспособностью, но и обеспечить его правильное хранение с целью поддержания начальной всхожести. Поэтому очень важно определить потенциал хранения (ПХ) генотипов перед закладкой на длительное хранение и провести градацию по данному признаку ценного коллекционного материала.

Для определения потенциала хранения семян в генетических банках растений различных стран используют тест на ускоренное старение семян (УСТ), который заключается в инкубации семян в условиях повышенной температуры и влажности, срок воздействия этими факторами на семена зависит от каждой конкретной культуры, а иногда и от конкретного генотипа (International Rules for Seed Testing, 2004). С помощью теста на УСТ семян можно осуществлять мониторинг коллекционных образцов растительного генофонда, что позволяет проводить постоянный учет их жизнеспособности и классифицировать генотипы из рабочих и активных коллекций по параметрам старения семян. С помощью данной методики можно:

1. выявлять образцы, не пригодные кдлительному хранению, что позволит сэкономить средства для консервации;

2. давать рекомендации по срокам воспроизводства семенного материала;

3. указать на необходимость восстановления жизнеспособности коллекционных образцов.

Целью настоящих исследований было изучить морфофизиологические и биохимические параметры после ускоренного старения семян кукурузы, позволяющие охарактеризовать их потенциал хранения, и провести градацию генотипов по данному признаку.

\section{Материалы и методы}

Объектами исследований служили районированные гибриды кукурузы из генетического банка растений Молдовы. Для определения ПХ семян использовали тест на УСТ (Handbook of vigor test methods, 1995). Тест проводили при температуре воздуха $42-44{ }^{\circ} \mathrm{C}$, влажности воздуха 90 - $100 \%$, срок старения 96 часов, после чего семена проращивали в чашках Петри в термостате при температуре $25^{\circ} \mathrm{C}$. В каждом варианте число семян составляло 300 штук. Определяли следующие морфофизиологические и биохимические параметры семян и проростков: энергию прорастания (ЭП) и всхожесть (В) семян, длину основного корешка (ДК), сырую и сухую биомассу корешков (СБК) проростков (Handbook of vigor test methods, 1995), содержание фермента пероксидазы (ПО) в корешках проростков (Ермаков и др., 1987), электропроводность растворов (International Rules for Seed Testing, 2004). Полученные результаты были обработаны с помощью пакета программ Statistica 7.

\section{Результаты и их обсуждение}

После проведения теста на УСТ семян кукурузы было обнаружено уменьшение значений всех морфофизиологических параметров у состаренных семян по сравнению с нормальными. Эти изменения проявились в большей или меньшей степени в зависимости от генотипа. В зависимости от уровня падения энергии прорастания семян генотипы кукурузы были подразделены на 3 группы: 
1. падение ЭП составило 10 - 15 \% (P402, Р280, Р310);

2. уменьшение ЭП составило 18 - 20 \% (P294, Р396, Р196, Р397, Р374);

3. ЭП упала на 25 - $30 \%$ (P461, Р262).

После учета всхожести состаренных семян генотипы были определены в 2 группы:

1. падение В составило 19 - 25 \% (Р402, Р461, Р294, Р196);

2. снижение В (рис. 1) составило 33 - 42 \% (Р396, Р397, Р374, Р 280, P262, Р310).

Обнаружено также уменьшение и других морфофизиологических параметров: длины корешков, длины проростков, сырой и сухой биомассы корешков. ДК корешков проростков после УСТ семян уменьшилась на 10 - 37 \% по отношению к контролю. Наиболее сильное торможение роста корешков проростков после УСТ наблюдалось у генотипов Р294, Р374, а наименьшее - у генотипов Р402 и Р196. При определении сырой и сухой биомассы корешков проростков кукурузы после УСТ семян проявилась аналогичная закономерность.

Сырая и сухая биомасса корешков уменьшилась на 17,3 - 55,1 \% и 10,0 - 65,5 \% соответственно по отношению к контролю. Очевидно, что наибольшее падение этих параметров у некоторых генотипов свидетельствует об их меньшей устойчивости к стрессовым условиям повышенной температуры и влажности.

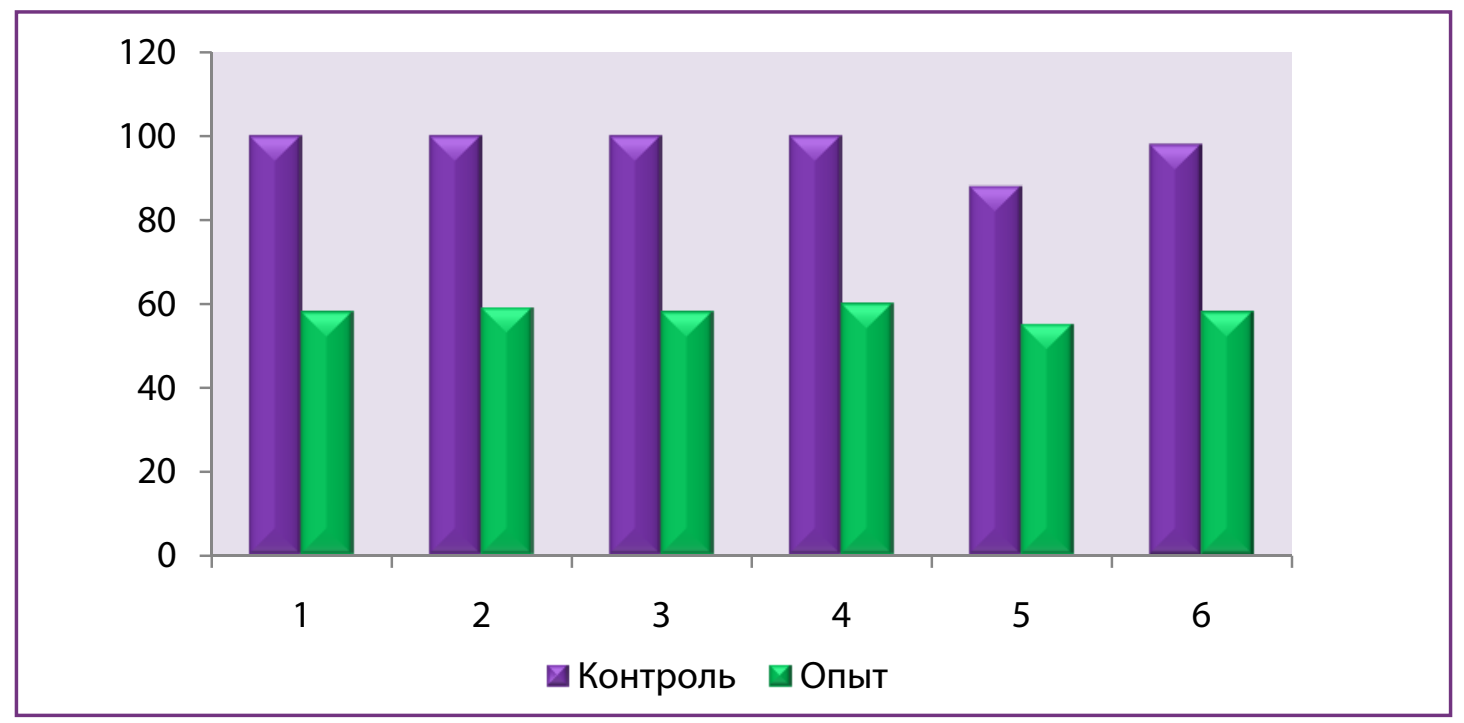

Рисунок 1 Всхожесть семян генотипов кукурузы после УСТ семян, \% (контроль и опыт)

Figure 1 Germinability of seeds of maize genotypes after AA, \% (control and experiment)

У всех генотипов кукурузы была выявлена значительная положительная корреляция параметра всхожести семян с энергией прорастания $(r=+0,55)$, длиной корешков $(r=+0,66)$, сырой $(r=+0,69)$ и сухой биомассой $(r=+0,53)$ корешков проростков. Параметр длина корешков также коррелировал с всхожестью $(r=+0,66)$, сырой $(r=+0,69)$ и сухой биомассой $(r=+0,58)$.

О выходе электролитов из семян кукурузы судили по электропроводности растворов с нормальными и состаренными семенами. Использовали временные экспозиции набухания семян - 24 и 48 часов. Хотя в Международных правилах ISTA предлагается использовать только 24-х часовую экспозицию, мы рекомендуем модифицировать данный метод для семян кукурузы посредством увеличения экспозиции набухания семян до 48 часов, т.к. именно при этой экспозиции более четко проявляется разница между вариантами. Электропроводность опытных растворов с состаренными семенами увеличилась после 48-часовой экспозиции 
в зависимости от генотипа в среднем на 13,0 - 97,0 \% по отношению к контролю. Существенные колебания данных свидетельствуют об индивидуальной специфичности коллекционных образцов кукурузы. Возрастание электропроводности растворов со старыми семенами объясняется увеличением проницаемости клеточных мембран после УСТ семян.

Содержание в корешках проростков семян кукурузы фермента пероксидазы после проведения теста на ускоренное старение увеличилось в 1,67 - 2,63 раза по сравнению с контролем в зависимости от конкретного генотипа, что является характерным при действии термического стресса. Наибольшее возрастание активности фермента в корешках проростков после проведения теста на ускоренное старение семян было отмечено у генотипов Р294, P260 и Р310 (табл. 1) (соответственно в 2,6; 2, 0 и 2,0 раза) по сравнению с контролем.

Таблица 1 Активность фермента пероксидазы в корешках проростков кукурузы после ускоренного старения семян, усл.ед

Table 1 Peroxidase enzyme activity in seedling rootlets after accelerated aging of maize seeds, c.u.

\begin{tabular}{|l|c|c|}
\hline Генотип & Контроль & Опыт \\
\hline P 402 & $1,50 \pm 0,20$ & $2,71 \pm 0,32^{*}$ \\
\hline P 461 & $1,70 \pm 0,13$ & $3,00 \pm 0,24^{*}$ \\
\hline P 294 & $1,37 \pm 0,17$ & $3,60 \pm 0,34^{*}$ \\
\hline P $\mathbf{3 9 6}$ & $1,00 \pm 0,06$ & $1,67 \pm 0,18^{*}$ \\
\hline P $\mathbf{3 6 6}$ & $0,90 \pm 0,12$ & $1,55 \pm 0,25^{*}$ \\
\hline P $\mathbf{3 9 7}$ & $0,79 \pm 0,10$ & $1,39 \pm 0,30^{*}$ \\
\hline P $\mathbf{3 7 4}$ & $0,59 \pm 0,06$ & $1,11 \pm 0,20$ \\
\hline P $\mathbf{2 6 0}$ & $0,74 \pm 0,09$ & $1,49 \pm 0,46$ \\
\hline P $\mathbf{2 6 2}$ & $1,09 \pm 0,15$ & $1,97 \pm 0,32$ \\
\hline P $\mathbf{3 1 0}$ & $0,50 \pm 0,09$ & $1,02 \pm 0,13^{*}$ \\
\hline
\end{tabular}

* разница существенна при $p \leq 0,05$; differences are significant with $p \leq 0,05$

Из анализа экспериментальных данных по совокупности различных параметров семян и проростков коллекционных образцов кукурузы наиболее высоким потенциалом хранения обладали генотипы P402, P294, P461, а наиболее низким - P374.

\section{Выводы}

Для проведения теста на ускоренное старение семян кукурузы предлагается использовать температуру воздуха $42-44{ }^{\circ} \mathrm{C}$ на протяжении 96-ти часов вместо температуры $41{ }^{\circ} \mathrm{C}$ на протяжении 72-х часов, рекомендуемых в Международных правилах анализа семян. Применение данного теста позволило выявить генотипические особенности коллекционных образцов кукурузы и распределить их по группам с учетом потенциальных возможностей сохранения жизнеспособности семян после воздействия стрессовых факторов. Показано, что электропроводность растворов с состаренными семенами у большинства генотипов выше, чем у растворов с нормальными семенами. С помощью морфофизиологических и биохимических параметров семян и проростков был определен потенциал хранения различных генотипов кукурузы, который является важной комплексной характеристикой коллекционных образцов при закладке их на длительное хранение в генетический банк растений. 


\section{Литература}

Aghilian, S., Khajeh-Hosseini, M. Anvarkhah, S. 2014. Evaluation of seed storage potential in forty medicinal plant species. International Journal of Agriculture and Crop Sciences, vol. 7, no. 10, p. 749-759. ISSN 2227-670X.

Demir, I. Mavi, K. 2008. Controlled deterioration and accelerated aging tests to estimate the relative storage potential of cucurbit seed lots. HortScience, vol. 43, no. 5, p. 1544-1548. ISSN 2327-9834.

Handbook of vigor test methods. ISTA. 1995. Zurich, Switzerland. $120 \mathrm{p}$.

Havstad, T., Aamlid, T., Lomholt, A. 2011. Evaluation of vigor tests for determination of seed storage potential in red clover (Trifolium pratensis L.) and timothy (Phleum pretense L.). Seeds Science and Technology, vol. 39, no. 3, p. 637-648. ISSN 1819-5717.

International rules for seed testing. 2004. The International Seed Testing Association (ISTA). Switzerland.

Nirmala, K., Umarani, R. 2014. Storage potential of primed seeds of okra (Abelmoschus esculentus) and beet root (Beta vulgaris). Australian Journal of Crop Sciences, vol. 8, no. 9, p. 1290-1297. ISSN 1835-2707.

Mielezrski, F., Marcos-Filho, H. 2013. Assessment of physiological potential of stored pea (Pissum sativum L.) seeds. Journal of Seed Science, vol. 35, no. 1, p. 42-50. ISSN 2317-1545.

Villela, F., Menezes, N. 2009. Seed storage potential. In Seed News, vol. 13, no. 4, p. 22-25. Available at: http://http://www.seednews.inf.br/

Ермаков, А., Арасимович, В., Ярош, Н. и др. 1987. Методы биохимического исследования растений. Москва, Колос, с. 42-43. 